\title{
Komórki satelitarne u pacjentów z mózgowym porazeniem dziecięcym - systematyczny przegląd piśmiennictwa
}

\section{Satellite cells in patients with cerebral palsy - a systematic literature review}

\author{
Aleksandra Popłonyk (D), Zofia Sajecka (D), Daria Siejka (D), Dominika K. Szymańska (D), Edyta Tekień (D), \\ Katarzyna Ostrzyżek-Przeździecka (D), Jakub S. Gąsior*iD \\ Oddział Fizjoterapii, Wydział Medyczny, Warszawski Uniwersytet Medyczny, ul. Żwirki i Wigury 61, 02-091 Warszawa \\ * Klinika Kardiologii Wieku Dziecięcego i Pediatrii Ogólnej, Warszawski Uniwersytet Medyczny, ul. Żwirki i Wigury 63A, 02-091 \\ Warszawa \\ DOI:10.20966/chn.2020.59.469
}

\section{STRESZCZENIE}

Wstęp. Mózgowe porażenie dziecięce (MPD) jest zaburzeniem neurologicznym spowodowanym niepostępującym uszkodzeniem ośrodkowego układu nerwowego (OUN) w okresie okotoporodowym lub niemowlęcym. Uszkodzenie OUN nie ma charakteru progresywnego, natomiast powoduje postępujące zmiany zarówno w kontroli nerwowej mięśni, jak i w ich strukturze. Częstym powikłaniem tej niepogłębiającej się patologii OUN są przykurcze mięśniowe. Jedną z teorii wyjaśniającą powstawanie przykurczy jest ograniczona liczba komórek satelitarnych. Są to komórki macierzyste mięśni, odpowiadające za ich wzrost, rozwój i regenerację po urazie. Udowodniono, że u pacjentów z MPD w mięśniu przykurczonym jest o 60-70\% mniej komórek satelitarnych niż w mięśniu osób zdrowych. Celem niniejszej pracy jest przedstawienie na podstawie systematycznego przeglądu piśmiennictwa zagadnienia dotyczącego komórek satelitarnych w grupie pacjentów z MPD.

Materiał i metody. Przegląd piśmiennictwa został przeprowadzony zgodnie z rekomendacjami PRISMA Statement. Przeszukano medyczną bazę danych MEDLINE/PubMed z wykorzystaniem słów kluczowych: "komórki satelitarne" (ang. satellite cells) w połączeniu z "mózgowe porażenie dziecięce" (ang. cerebral palsy).

Wyniki. W latach 2013-2021 zidentyfikowano 10 publikacji spełniających kryteria wyszukiwania, z tego 3 zakwalifikowano do szczegółowej analizy. Zanotowano znacznie mniejszą liczbę komórek satelitarnych w mięśniach, zmniejszoną liczbę włókien mięśniowych w obszarze dla każdej komórki satelitarnej, mniejszą łączną liczbę włókien mięśniowych, obniżenie szybkości tworzenia miotubuli u pacjentów z MPD w porównaniu do mięśni osób zdrowych.

Wnioski. Planując proces leczenia i rehabilitacji, zespoły terapeutyczne powinny brać pod uwagę zredukowaną zawartość komórek satelitarnych w mięśniach pacjentów z MPD.

Słowa kluczowe: mózgowe porażenie dziecięce; komórki satelitarne; przykurcze

\section{ABSTRACT}

Introduction. Cerebral Palsy (CP) is a neurological disorder caused by non-progressive damage to the central nervous system (CNS) in the perinatal or infantile period. The damage of the CNS causes progressive changes in the nervous control of the muscles and their structure. One theory of contracture development is satellite cells (SC) deficiency. SCs are muscle stem cells responsible for their growth, development and regeneration after an injury. The aim of this study is to present, based on a systematic review of the literature, the issue of SCs in a group of patients with CP.

Material and methods. The systematic literature review was carried out according to PRISMA statement recommendations. MEDLINE/PubMed database was review using the key phrases: 'satellite cells' and 'cerebral palsy'.

Results. Between 2013 and 2021, 10 publications were identified, of which 3 were selected for detailed analysis. Significantly lower number of SCs was observed, also a reduced number of muscle fibers in the region for each SC, a smaller total number of muscle fibers, a reduction in the rate of fusion and myotubule formation in patients with CP.

Conclusions. When planning a treatment and rehabilitation process, medical teams should take into account the reduced number of muscle SCs in patients with $\mathrm{CP}$.

Key words: cortisol, autism spectrum disorder, children.

\section{WSTĘP I CEL PRACY}

Mózgowe porażenie dziecięce (MPD) jest zaburzeniem neurologicznym spowodowanym niepostępującym uszkodzeniem ośrodkowego układu nerwowego (OUN) w okresie okołoporodowym lub niemowlęcym. MPD opisuje grupę trwałych zaburzeń rozwoju ruchu i postawy, powodujących ograniczenie aktywności ruchowej. Zaburzeniom motoryki często towarzyszą zaburzenia czucia, percepcji, poznawcze, porozumiewania się i zachowania, padaczka oraz wtórne problemy mięśniowo-szkieletowe [1, 2]. MPD jest najczęściej występującym zaburzeniem neurologicznym, które powoduje niepełnosprawność u dzieci. Na świecie rozpoznawane jest u 2-3 przypadków na 1000 
żywo urodzonych dzieci [3, 4]. Jak wynika z najnowszych raportów międzynarodowych, częstość urodzeń dzieci z MPD spada w krajach wysokorozwiniętych do 1,4 na 1000 żywo urodzonych dzieci, co oznacza $35 \%$ spadek częstości urodzeń w ciągu 15 lat [5].

Określenie „niepostępujące zaburzenie neurologiczne”, ujęte w definicji MPD, wskazuje na to, iż mechanizmy patofizjologiczne prowadzące do dysfunkcji wynikają z pojedynczego zdarzenia w obrębie OUN, które nie postępuje w momencie diagnozy. Zaburzenie to powoduje zakłócenie normalnej struktury i czynności mózgu, które w połączeniu z procesami rozwojowymi może być powiązane ze zmieniającymi się w czasie, lub dodatkowymi objawami [1] Samo uszkodzenie OUN nie ma charakteru progresywnego, niemniej jednak, u pacjentów z MPD powoduje postępujące zmiany zarówno w kontroli nerwowej mięśni, jak i w samej ich budowie [6]. U pacjentów ze spastycznym typem napięcia, mięśnie są skrócone, co wynika głównie ze zredukowanej długości brzuśca, a w mniejszym stopniu ze zredukowanej długości ścięgien [4].

Wielu badaczy starało się znaleźć przyczynę powstawania przykurczy u pacjentów z MPD [7]. Złożoną kwestią jest proces skracania się mięśnia i jego pogłębianie w czasie, w kontraście do niepogłębiającej się patologii OUN. Przykurcz mięśni szkieletowych definiowany jest jako trwałe skrócenie jednostki mięśniowo-ścięgnistej powodujące zmniejszenie jej elastyczności, w konsekwencji utratę możliwości rozciągania biernego oraz rozciągania poprzez aktywację mięśni antagonistycznych, a w skrajnych przypadkach deformację stawów [7].

Rozwój mięśni szkieletowych odbywa się w sposób podłużny i radialny. Wzrost podłużny związany jest ze zwiększającym się zakresem ruchu, w którym funkcjonuje mięsień, natomiast wzrost radialny wpływa na zwiększanie się siły skurczu mięśnia [8]. Zmieniająca się liczba sarkomerów jest jednym z mechanizmów adaptacyjnych zarówno w procesie rozwoju i wzrostu mięśni, ale także przy unieruchomieniu w pozycji skróconej lub wydłużonej [8]. Wykazano, że w skróconym mięśniu, jak i wydłużonym, zmienia się liczba sarkomerów w celu zachowania ich optymalnej długości. U dzieci z MPD zauważono zmniejszoną objętość brzuśca oraz skróconą długość całego mięśnia w porównaniu z dziećmi rozwijającymi się prawidłowo, co wskazuje na nieprawidłowy rozwój zarówno podłużny jaki i radialny mięśni [3]. Badania charakterystyki fizjologicznej mięśni u pacjentów z MPD są w ostatnim czasie wspierane przez badania oceniające komórki macierzyste mięśni szkieletowych, tzw. komórki satelitarne (MSC, ang. muscle satellite cells). Komórki satelitarne są odpowiedzialne za wzrost podłużny oraz poprzeczny mięśni. Uczestniczą też w naprawie mięśni po urazie. Położone są peryferyjnie, pomiędzy sarkolemmą, a błoną podstawną włókna mięśniowego. Podobne są pod względem umiejscowienia do jąder komórkowych mięśni szkieletowych, jednak znajdują się poza sarkolemmą, podczas gdy jądra umiejscowione są tuż pod nią. Jako komórki macierzyste mają możliwość autoregeneracji [8]. U prawidłowo rozwijającego się dziecka komórki satelitarne proliferują, a następnie w postaci mioblastów łączą się ze sobą tworząc stadium pośrednie, które finalnie prowadzi do powstania wielojądrowego włókna mięśniowego. Przy zmniejszonej puli komórek macierzystych, zmniejszają się zdolności do wzrostu i regeneracji mięśnia oraz zwiększają się predyspozycje do włóknienia tkanki mięśniowej $[4,8]$.

Celem niniejszej pracy jest przedstawienie na podstawie systematycznego przeglądu piśmiennictwa zagadnienia dotyczącego komórek satelitarnych w grupie pacjentów z MPD.

\section{MATERIAL I METODY}

Przegląd piśmiennictwa został przeprowadzony zgodnie $\mathrm{z}$ rekomendacjami PRISMA Statement (ang. Preferred Reporting Items for Systematic Reviews and Meta-Analyses) [9]. W celu identyfikacji publikacji naukowych przeszukano medyczną bazę danych MEDLINE/PubMed z wykorzystaniem następujących słów/zwrotów kluczowych: „komórki satelitarne” (ang. satellite cells) w połączeniu z „mózgowe porażenie dziecięce” (ang. cerebral palsy) znajdujących się w tytule i/lub streszczeniu publikacji (link: https://pubmed.ncbi.nlm.nih.gov/?term $=\% 28 \% 22$ satellite + cells $\% 22 \% 5$ BTitle $\% 2$ FAbstract $\% 5 D \% 29+A N D+\% 28 \%$ 22 cerebral + palsy $\% 22 \% 5$ BTitle $\% 2 F A$ bstract $\% 5 D \% 29 \& s$ ort $=$ pubdate).

Wyłączono badania przeprowadzone na modelu zwierzęcym oraz przeglądy piśmiennictwa. Proces wyszukiwania z wykorzystaniem słów/zwrotów kluczowych pozwolił zidentyfikować 10 artykułów z dostępem do pełnego tekstu w języku angielskim. Wykorzystując narzędzie (strategię wyszukiwania) PICO (każda litera akronimu PICO odnosi się do: $\mathrm{P}$ - populacji pacjentów lub choroby, której dotyczy problem; I - przeprowadzonej interwencji, C grupy kontrolnej; $\mathrm{O}$ - wyników/punktów), wyodrębniono z każdego badania następujące informacje: pierwszy autor i rok badania, cel badania, charakterystyka uczestników (opis grupy eksperymentalnej - pacjenci z MPD; opis grupy kontrolnej - uczestnicy z typowym rozwojem), zastosowana interwencja, oraz główne wyniki badania, które przedstawiono $\mathrm{w}$ Tabeli I.

\section{WYNIKI}

Spośród 10 publikacji, wyszukanych podczas fazy identyfikacji artykułów, do finalnej analizy zakwalifikowano 3 artykuły $[4,10,11]$.

\section{Uczestnicy}

We włączonych do przedstawionego przeglądu piśmiennictwa badaniach opublikowanych w latach 20132021 autorzy analizowali wyniki łącznie 22 pacjentów z MPD. Szczegóły dotyczące płci i wieku oraz w jednym badaniu poziomu sprawności ocenionego w klasyfikacji funkcji motoryki dużej (GMFCS, ang. Gross Motor Function Classification System) zostały przedstawione w Tabeli I. Dane dotyczące grupy kontrolnej dostępne były we wszystkich badaniach i obejmowały 21 uczestników z typowym rozwojem. 


\section{Mierzone parametry}

Mierzono następujące parametry: rozkład komórek satelitarnych w przekroju poprzecznym, liczbę włókien mięśniowych/obszar dla każdej SC oraz zmianę obszaru włókien mięśniowych wraz z wiekiem. W podanych badaniach zastosowana została również strategia bramkowania FMO (ang. fluorescence minus one) do identyfikacji komórek satelitarnych, która polega na zastosowaniu fluorescencji (2 badanie w Tabeli I), a także pomiar impedancji komórek w okresie 42 godzin ( 3 badanie w Tabeli I).

Tab. I. Charakterystyka publikacji włączonych do badania Characteristics of the publications included in the study

\begin{tabular}{|c|c|c|c|c|c|c|}
\hline \multirow{2}{*}{$\begin{array}{c}\text { Pierwszy } \\
\text { autor, rok } \\
\text { badania } \\
\text { First } \\
\text { author, } \\
\text { year of } \\
\text { the study }\end{array}$} & \multirow{2}{*}{$\begin{array}{c}\text { Cel badania } \\
\text { Aim of the study }\end{array}$} & \multirow{2}{*}{$\begin{array}{c}\text { Opis grupy } \\
\text { eksperymenta- } \\
\text { Inej } \\
\text { Description of the } \\
\text { study group }\end{array}$} & \multirow{2}{*}{$\begin{array}{c}\text { Opis grupy } \\
\text { kontrolnej } \\
\text { Description } \\
\text { of the } \\
\text { control } \\
\text { group }\end{array}$} & \multicolumn{3}{|c|}{ Wyniki Results } \\
\hline & & & & $\begin{array}{l}\text { Badany parametr } \\
\text { Studied parameter }\end{array}$ & $\begin{array}{l}\text { Grupa pacjentów } \\
\text { z MPD } \\
\text { Group of patients } \\
\text { with } \mathrm{CP}\end{array}$ & $\begin{array}{l}\text { Grupa } \\
\text { kontrolna } \\
\text { Control } \\
\text { group }\end{array}$ \\
\hline $\begin{array}{c}\text { Dayanidhi } \\
\text { i wsp., 2015 } \\
\text { [10] }\end{array}$ & $\begin{array}{c}\text { Użycie badania } \\
\text { immunohistochemicznego } \\
\text { na skrawkach mięśni } \\
\text { objętych przykurczami } \\
\text { u dzieci z MPD w celu } \\
\text { oceny ilościowej komórek } \\
\text { satelitarnych in situ, bez } \\
\text { manipulacji tkankami }\end{array}$ & $\begin{array}{c}6 \text { dzieci z MPD (6 } \\
\text { chłopców) w wieku } \\
12,9 \pm 3,4 \text { lat }\end{array}$ & $\begin{array}{c}5 \text { dzieci } \\
\text { z normalnym } \\
\text { rozwojem } \\
\text { (1 chłopiec) } \\
\text { w wieku } \\
15,1 \pm 2,0 \\
\text { lat }\end{array}$ & \begin{tabular}{|} 
Liczba komórek satelitarnych \\
(SC) (SC/100 miofibryli): \\
Rozkład SC w przekroju \\
poprzecznym (SC/ \\
microscopic field): \\
Średni odsetek pól, w \\
których nie było SCs: \\
Liczba pól z tylko jedną SC: \\
Liczba pól z więcej niż jedną \\
SC: \\
SC, które były jedynymi \\
komórkami w polu: \\
Liczba wókien mięśniowych/ \\
obszar dla każdej SC i \\
domeny nuklearnej liczba \\
wtókien mięśniowych na SC: \\
Domena SC (średni region \\
pokrycia na SC): \\
Gęstość SC (liczba SC na \\
mm2): \\
Całkowita liczba wtókien \\
mięśniowych: \\
tączna liczba obszarów \\
wtókien mięśniowych: \\
Liczba jąder na 100 włókien \\
mięśniowych: \\
Domena jądrowa (średni \\
region pokrycia na jądro): \\
Zmiana obszaru włókien \\
mięśniowych wraz z \\
wiekiem (wzrost obszaru \\
włókien mięśniowych):
\end{tabular} & $\begin{array}{c}2.89 \pm 0.39 \\
0.16 \pm 0.11 \\
86 \pm 7 \% \\
12 \pm 4 \% \\
2 \pm 3 \% \\
92 \pm 8 \% \\
35.2 \pm 4.9 \\
194,000 \pm 50,000 \\
\mathrm{~mm} 2 \\
6.30 \pm 1.85 \\
1,192 \pm 827 \\
3,712 \pm 1,065 \\
\mathrm{~mm}^{2} \\
182.5 \\
2,099 \pm 848 \mathrm{~mm}^{2} \\
143 \mathrm{~mm}^{2} / \mathrm{rok}\end{array}$ & $\begin{array}{c}8.77 \pm \\
0.79 \\
\\
0.42 \pm \\
0.18 \\
\\
68 \pm 11 \% \\
24 \pm 6 \% \\
8 \pm 5 \% \\
65 \pm 17 \% \\
\\
11.5 \pm \\
1.1 \\
72,000 \pm \\
26,000 \\
\mathrm{~mm} 2 \\
15.18 \pm \\
3.83 \\
\\
1,062 \pm \\
619 \\
\\
4,546 \pm \\
1,494 \\
\mathrm{~mm} 2 \\
\\
224.3 \\
\\
1,762 \pm \\
672 \mathrm{~mm} \\
255 \mathrm{~mm} 2 \\
\mathrm{rok}\end{array}$ \\
\hline $\begin{array}{c}\text { Smith } \\
\text { i wsp., } 2013 \\
\text { [11] }\end{array}$ & $\begin{array}{l}\text { Wyjaśnienie zjawiska } \\
\text { zmniejszonej liczby } \\
\text { populacji komórek } \\
\text { satelitarnych w } \\
\text { skurczonym mięśniu. }\end{array}$ & $\begin{array}{c}8 \text { dzieci z MPD } \\
\text { (6 chłopców, } 2 \\
\text { dziewczynki) w } \\
\text { wieku od } 6 \text { do } 15 \\
\text { roku życia }\end{array}$ & $\begin{array}{c}8 \text { dzieci z } \\
\text { normalnym } \\
\text { rozwojem (6 } \\
\text { chłopców, } \\
2 \\
\text { dziewczynki) } \\
\text { w wieku od } \\
15 \text { do } 18 \text { roku } \\
\text { życia }\end{array}$ & $\begin{array}{c}\text { Liczba komórek } \\
\text { jednojądrzastych: } \\
\text { Liczba komórek satelitarnych } \\
\text { zidentyfikowanych za } \\
\text { pomocą metody FMO: } \\
\text { Liczba komórek zapalnych } \\
\text { (CD45+ / CD34): } \\
\text { Liczba komórek śródbłonka } \\
\text { (CD45 / CD34+): }\end{array}$ & $\begin{array}{l}39,0 \pm 5,4 \% \\
5,3 \pm 2,3 \% \\
6,7 \pm 1,0 \% \\
17,1 \pm 2,4 \%\end{array}$ & $\begin{array}{c}41,8 \pm \\
6,0 \% \\
\\
12,8 \pm \\
2,8 \% \\
\\
7,5 \pm \\
1,6 \% \\
17,8 \pm \\
1,6 \%\end{array}$ \\
\hline
\end{tabular}




\begin{tabular}{|c|c|c|c|c|c|c|}
\hline $\begin{array}{c}\text { Domenighetti } \\
\text { i wsp., } 2018 \\
{[4]}\end{array}$ & $\begin{array}{c}\text { Zmierzenie potencjału } \\
\text { miogennych komórek } \\
\text { satelitarnych izolowanych } \\
\text { z przykurczonych mięśni } \\
\text { u dzieci } \\
\text { z porażeniem mózgowym } \\
\text { i porównanie ich z dziećmi } \\
\text { rozwijającymi się typowo. }\end{array}$ & $\begin{array}{c}8 \text { dzieci z } \\
\text { porażeniem } \\
\text { mózgowym, w } \\
\text { wieku 3-18 lat. } \\
\text { Uczestnicy mieli } \\
\text { zdiagnozowane } \\
\text { porażenie } \\
\text { mózgowe, poziomy } \\
\text { I-V wg GMFCS. } \\
\text { U wszystkich } \\
\text { pacjentów } \\
\text { wystąpił przykurcz } \\
\text { wymagający } \\
\text { operacji, } \\
\text { pomimo leczenia } \\
\text { zachowawczego }\end{array}$ & $\begin{array}{c}8 \text { dzieci z } \\
\text { typowym } \\
\text { rozwojem, } \\
\text { średnio } 6 \\
\text { lat starsze } \\
\text { niż dzieci } \\
\text { z grupy } \\
\text { badawczej }\end{array}$ & $\begin{array}{c}\text { Impedancja komórek w } \\
\text { okresie } 42 \text { h: } \\
\text { - szybkości fuzji i tworzenia } \\
\text { miotubuli: } \\
\text { - wskaźnik fuzji } 42 \mathrm{~h} \text { po } \\
\text { różnicowaniu: }\end{array}$ & $\begin{array}{c}0,013 \pm 0,013 \\
21,3 \pm 8,6\end{array}$ & $\begin{array}{c}0,091 \pm \\
0,024 \\
\\
81,3 \pm \\
7,7\end{array}$ \\
\hline
\end{tabular}

\section{DYSKUSJA}

W przedstawionej pracy dokonano systematycznego przeglądu piśmiennictwa dotyczącego komórek satelitarnych w grupie pacjentów z MPD. W analizowanych badaniach zaobserwowano występowanie znacznie zmniejszonej liczby komórek satelitarnych, mniejszą liczbę włókien mięśniowych w obszarze dla każdej komórki satelitarnej, obniżoną łączną liczbę włókien mięśniowych oraz spowolnienie fuzji i tworzenia miotubuli u pacjentów z MPD w porównaniu do grupy kontrolnej osób zdrowych.

Postnatalny rozwój mięśni charakteryzuje się poprzecznym oraz podłużnym wzrostem włókien mięśniowych. Poprzeczny wzrost mięśnia powoduje zwiększenie siły mięśniowej, natomiast wzrost podłużny zwiększa zakres ruchu w stawie, za który odpowiedzialny jest ten mięsien. Wzrost włókien możliwy jest dzięki komórkom satelitarnym [8], które odpowiedzialne są także za regenerację, naprawę i adaptację włókien mięśniowych [3, 7, 12-14]. Proces aktywacji komórek satelitarnych do produkcji miofibryli, składa się z określonych kroków: od uśpienia, poprzez proliferację, różnicowanie, aż do fuzji komórek [8]. Komórki satelitarne pozostają $\mathrm{w}$ stanie uśpienia, aż do momentu ich aktywacji w wyniku różnego rodzaju urazów, m.in.: mechanicznych bądź chorobowych [3, 7, 12-14]. Mogą zostać aktywowane przez mechaniczne rozciąganie, które jest istotne w rozwoju człowieka, gdzie wzrost kości pośredniczy we wzroście mięśni. Istnieje również wiele innych aktywatorów komórek satelitarnych takich jak czynniki: FGF (ang. fibroblast growth factor), IGF (ang. insuline-like growth factor), HGF (ang. hepatocyte growth factor) oraz MMPs (ang. matrix metalloproteinase), które pełnią istotną funkcję $\mathrm{w}$ remodelingu macierzy zewnątrzkomórkowej oraz są promotorami migracji komórek satelitarnych, co umożliwia lepszą regenerację uszkodzonego mięśnia [8, 12-14]. Również ścieżka sygnałowa Wnt (ang. Wnt signaling pathway) odgrywa ważną rolę podczas aktywacji i proliferacji komórek satelitarnych. Aktywacja szlaku Wnt powoduje, że komórki układają się w sposób, który umożliwia podział każdej z nich na: satelitarną oraz aktywną, która później stanie się mioblastem. Dzięki temu procesowi ogólna liczba komórek satelitarnych w mięśniu nie zmniejsza się [8].

Przykurcze powodowane są problemami zarówno z radialnym, jak i podłużnym wzrostem mięśni. Długość oraz całkowity przekrój pęczków włókien mięśniowych są podobne u pacjentów z MPD i u dzieci zdrowych. Niemniej jednak, przekrój pojedynczego włókna oraz liczba sarkomerów są mniejsze u pacjentów z MPD w porównaniu z dziećmi rozwijającymi się prawidłowo $[4,10]$. Sugeruje się, że może istnieć biologiczna lub strukturalna bariera wzrostu w skurczonym mięśniu. Jako pierwsza przyczyna tych zaburzeń nasuwa się zmniejszona liczba komórek satelitarnych, które są źródłem mioblastów niezbędnych do wzrostu i regeneracji. Wykazano, że liczba komórek satelitarnych u dzieci z MPD zmniejsza się po urodzeniu zarówno w mięśniach antagonistach i agonistach, a dokładna przyczyna spadku ich liczby nie została jeszcze jednoznacznie określona. Autorzy badań tkanki mięśniowej pobranej od pacjentów z MPD wykazali, że populacja komórek satelitarnych odpowiedzialnych za regenerację jest zmniejszona nawet o $60-70 \% \mathrm{w}$ mięśniach przykurczonych w tej grupie w porównaniu do mięśni osób zdrowych $[4,8]$. Z powodu obniżenia liczby komórek odpowiedzialnych za naprawę, mięśnie nie podlegają odbudowie, co skutkuje nasileniem skurczu, jak i brakiem rozkurczu [11]. Co ciekawe, autorzy badań wykorzystujący model zwierzęcy wykazali, że zmniejszenie liczby komórek satelitarnych (do liczby podobnej jaka występuje u dzieci z MPD) nie wywołało zmniejszonego przyrostu podłużnego, ani poprzecznego mięśnia. Wskazuje to, że hipertrofia oraz wzrost podłużny mięśnia pozbawionego komórek satelitarnych jest możliwy. Dodatkowo, w pęczkach włókien mięśniowych widać było różnicę w stosunku ilości macierzy pozakomórkowej do grubości włókien mięśniowych [15].

Ilość macierzy u dzieci z MPD jest znacznie większa. Zmiany dotyczą również zwiększenia ilości oraz odmiennego rozmieszczenia kolagenu, co przyczynia się do zwiększonej sztywności mięśni. W przykurczonych mięśniach u dzieci z MPD obserwuje się wydłużone sarkome- 
ry. To z kolei przyczynia się do generowania bardzo niskiego napięcia w nieprawidłowej części zakresu ruchu. Tak zmienione mięśnie są bardzo słabe i nie spełniają swojej funkcji [10]. Różnicę w strukturze mięśni między dziećmi z MPD a zdrowymi rówieśnikami zauważono również badając łańcuch ciężki miozyny, determinujący rodzaj włókna mięśniowego. Dzieci z MPD wykazywały znaczną przewage jednego rodzaju włókien [3].

U większości pacjentów z MPD, wraz z dojrzewaniem często występują przykurcze. Ograniczają one prawidłowy zakres ruchu w stawach, upośledzają postawę, równowagę oraz fizjologiczny wzorzec chodu, zmniejsza się także ilość produkowanej siły. Ogranicza to niezależność w wykonywaniu czynności dnia codziennego, doprowadzając do zmniejszenia uczestnictwa jednostki w społeczeństwie, a tym samym do pogłębienia izolacji społecznej [3]. W grupie pacjentów z MPD jedną z form terapii zapobiegania i zmniejszania przykurczy jest rehabilitacja [16]. Ćwiczenia siłowe i wytrzymałościowe, stosowane bez przerwy mogą powodować wzrost liczby komórek satelitarnych o 20-30\%, jednakże po ich przerwaniu liczba komórek wraca do stanu wyjściowego już po kilkunastu dniach. Niestety wykonywanie ćwiczeń siłowych/oporowych jest często ograniczone u pacjentów z MPD. Jednym z powodów jest mała liczba komórek satelitarnych, podlegających aktywacji pod wpływem ćwiczeń oporowych. Zbyt mała liczba komórek satelitarnych powoduje, iż chronicznie rozciągnięte mięśnie nie są w stanie odbudowywać i dobudowywać sarkomerów [10].

Inną powszechnie stosowaną formą rehabilitacji przykurczy u pacjentów z MPD jest rozciąganie mięśni/grup mięśniowych. Aby nastąpiło wydłużenie włókien, konieczne jest dostarczenie odpowiedniej siły rozciągającej. Stopień rozciągnięcia zależy od właściwości mechanicznych zarówno tkanki kurczliwej, jak i tkanki łącznej w obrębie włókien mięśniowych i ścięgna. Wykazano, że podczas biernego zgięcia grzbietowego stawu skokowego u dzieci z MPD głowa przyśrodkowa mięśnia brzuchatego łydki wydłuża się w mniejszym zakresie, w porównaniu z typowo rozwijającymi się dziećmi. Rozciąganie może być korzystne w zapobieganiu progresji przykurczów mięśni. Jednak jako wyizolowana forma terapii, nie sprzyja wzrostowi długości mięśni, ani nie wpływa na poprawę funkcji w tej grupie pacjentów. Wydaje się, że mięsień nie otrzymuje wystarczającej siły bodźca rozciągającego, co może wyjaśniać ograniczone zmiany w strukturze mięśni/ ścięgien. Należy stosować alternatywne podejścia w celu zwiększenia skuteczności ćwiczeń rozciągających, m.in połączenie rozciągania $\mathrm{z}$ iniekcją toksyny botulinowej, czy z ćwiczeniami oporowymi. Leczeniem skojarzonym zwiększającym bodziec rozciągający będzie również zastosowanie elektrostymulacji mięśnia antagonisty wraz z ćwiczeniami rozciągającymi [17].

W 2017 roku w Klinice Rehabilitacji Dziecięcej z Ośrodkiem Wczesnej Pomocy Dzieciom Upośledzonym „Dać Szansę” Uniwersytetu Medycznego w Białymstoku przeprowadzono badania z zastosowaniem czynnika stymulującego kolonię granulocytów (GCS-F, ang. granulo- cyte colony-stimulating factor) u dzieci z MPD. GCS-F to glikoproteina, która stymuluje szpik kostny do wytwarzania granulocytów i komórek macierzystych oraz uwalnia je do krwi. Wykazano, że dzięki zastosowaniu tej metody uzyskano poprawę m.in. w zakresie motoryki pacjenta poprzez wpływ na mechanizmy komórkowe mięśni szkieletowych [18]. W 2021 roku opublikowano artykuł, którego celem był przegląd aktualnej wiedzy dotyczącej patofizjologii przykurczów mięśni w MPD [19]. U młodszych dzieci z MPD skurcz ma charakter dynamiczny, natomiast $\mathrm{u}$ starszych pacjentów przybiera on charakter statyczny - dochodzi do skrócenia mięśnia. Oba rodzaje przykurczy przyczyniają się do zaburzeń chodu, problemów z siedzeniem oraz do zwichnięć stawów. Według autorów przykurcz jest skutkiem zaburzonej postawy, jednak biorąc pod uwagę patomorfologię mięśni manifestującą się: nieprawidłowościami na poziomie sarkomerów, zmniejszeniem liczby komórek satelitarnych, zwiększeniem ilości tkanki łącznej oraz tłuszczowej, a także wysoce elastycznymi miofibrylami, dzisiejsze odkrycia pozwalają podważyć tę hipotezę. Nasuwa się wniosek, że przyczyna przykurczy może koncentrować się w obrębie tkanki mięśniowej. W publikacji wyróżniono 4 główne komponenty mechaniczno-strukturalne, które znacząco wpływają na funkcję mięśni: zmniejszony rozmiar mięśnia, zredukowana kurczliwość tkanki, nadmiernie rozciągnięte sarkomery, zmniejszenie ilości tytyny w sarkomerach. Autorzy zwracają również uwagę na zredukowaną liczbę komórek satelitarnych w mięśniach dzieci z MPD. Chociaż liczba badań nad patofizjologią mięśni w MPD rośnie, wciąż pozostaje wiele pytań bez odpowiedzi, szczególnie w odniesieniu do rozwoju trwałych przykurczy, zmniejszonego wzrostu mięśni i ich osłabienia. Rozważenie wszystkich dotychczasowych doniesień o patofizjologii mięśni w MPD może okazać się niezmiernie pomocne w planowaniu interwencji terapeutycznych dla dzieci z tym schorzeniem.

Formy leczenia i rehabilitacji wpływające na poprawę stanu klinicznego pacjenta z MPD na trzech poziomach ICF, stymulujące aktywne jego uczestnictwo w zadaniach motorycznych, ukierunkowane na osiągnięcie funkcjonalnego celu terapeutycznego są kluczowe dla osiągnięcia przez pacjenta społecznej niezależności. Planując proces leczenia i rehabilitacji, multidyscyplinarne zespoły terapeutyczne powinny pamiętać o zredukowanej zawartości komórek satelitarnych w mięśniach u pacjentów z MPD.

\section{PIŚMIENNICTWO}

[1] Rosenbaum P., Paneth N., Leviton A., et al.: A report: the definition and classification of cerebral palsy April 2006. Dev Med Child Neurol Suppl. 2007; 109: 8-14.

[2] Graham HK., Rosenbaum P., Paneth N., et al.: Cerebral palsy. Nat Rev Dis Primers. 2016; 2: 15082

[3] Mathewson MA., Lieber RL.: Pathophysiology of muscle contractures in cerebral palsy. Phys Med Rehabil Clin N Am. 2015; 26: 57-67.

[4] Domenighetti AA., Mathewson MA., Pichika R., et al.: Loss of myogenic potential and fusion capacity of muscle stem cells isolated from contractured muscle in children with cerebral palsy. Am J Physiol Cell Physiol. 2018; 315(2): C247-C257.

[5] Badawi N., Mcintyre S., Hunt RW.: Perinatal care with a view to preventing cerebral palsy. Dev Med Child Neurol. 2021; 63: 156-161. 
6] Tisha AL., Armstrong AA., Wagoner Johnson A., et al.: Skeletal Muscle Adaptations and Passive Muscle Stiffness in Cerebral Palsy: A Literature Review and Conceptual Model. J Appl Biomech. 2018: 1-37.

[7] Lieber RL., Fridén J.: Muscle contracture and passive mechanics in cerebral palsy. J Appl Physiol (1985). 2019; 126: 1492-1501.

[8] Dayanidhi S., Lieber RL.: Skeletal muscle satellite cells: mediators of muscle growth during development and implications for developmental disorders. Muscle Nerve. 2014; 50: 723-732.

[9] Liberati A., Altman DG., Tetzlaff J., et al.: The PRISMA statement for reporting systematic reviews and meta-analyses of studies that evaluate healthcare interventions: explanation and elaboration. BMJ. 2009; 339: b2700.

[10] Dayanidhi S., Dykstra PB., Lyubasyuk V., et al.: Reduced satellite cell number in situ in muscular contractures from children with cerebral palsy. J Orthop Res. 2015; 33: 1039-1045.

[11] Smith LR., Chambers HG., Lieber RL.: Reduced satellite cell population may lead to contractures in children with cerebral palsy. Dev Med Child Neurol. 2013; 55: 264-270.

[12] Relaix F., Zammit PS.: Satellite cells are essential for skeletal muscle regeneration: the cell on the edge returns centre stage. Development. 2012; 139: 2845-56.
[13] Snijders T., Nederveen JP., McKay BR., et al.: Satellite cells in human skeletal muscle plasticity. Front Physiol. 2015; 6: 283.

[14] Forcina L., Miano C., Pelosi L., et al.: An Overview about the Biology of Skeletal Muscle Satellite Cells. Curr Genomics. 2019; 20: 24-37.

[15] Dayanidhi S., Kinney MC., Dykstra PB., et al.: Does a Reduced Number of Muscle Stem Cells Impair the Addition of Sarcomeres and Recovery from a Skeletal Muscle Contracture? A Transgenic Mouse Model. Clin Orthop Relat Res. 2020; 478: 886-899.

[16] Novak I., Morgan C., Fahey M., et al.: State of the Evidence Traffic Lights 2019: Systematic Review of Interventions for Preventing and Treating Children with Cerebral Palsy. Curr Neurol Neurosci Rep. 2020; 20: 3.

[17] Kalkman BM., Bar-On L., O'Brien TD., et al.: Stretching Interventions in Children With Cerebral Palsy: Why Are They Ineffective in Improving Muscle Function and How Can We Better Their Outcome? Front Physiol. 2020; 11: 131.

[18] Paszko-Pataj G., Sienkiewicz D., Okurowska-Zawada B., et al.: Granulocyte colony-stimulating factor potential use in the treatment of children with cerebral palsy. Prog Health Sci. 2017; 7: 187-192.

[19] Howard JJ., Herzog W.: Skeletal Muscle in Cerebral Palsy: From Belly to Myofibril. Front Neurol. 2021; 12: 620852. 